\title{
Women Teaching Peace: Shaping the Thought and Action of Future Generations
}

\author{
Jasmin Nario-Galace
}

\begin{abstract}
This study investigates the effects of a peace education camp, designed and organized by women peace advocates, in shaping the beliefs and attitudes of youth leaders after a violent incident that threatened the gains of a peace process in the Philippines. The study uses quantitative methodology and a two observation (pretest-posttest) design. Seventy students participated in the research. The Beliefs and Attitudes toward Peace Issues (BATPI) scale developed by the researcher was employed. Data analysis procedures used the t-test for paired samples. Results showed that beliefs and attitudes of participants toward peace and the peace process significantly improved after the peace education camp. Implications and applications of findings are discussed and recommendations are offered.
\end{abstract}

Keywords peace, peace education, peace process, women's agency, youth agency

\section{Introduction}

In the year 2000, the United Nations Security Council (UNSC) adopted UNSC Resolution (UNSCR) 1325 that acknowledged the important role women play in different aspects of peace work: conflict resolution, conflict prevention, peacekeeping, and peacebuilding, among others. Acknowledging that peace becomes more sustainable when women are involved, UNSCR 1325 encourages United Nations (UN) member states to increase women's participation and leadership in these efforts. In 2010, the Philippines adopted a National Action Plan (NAP) to implement UNSCR 1325, the first in Asia to do so. However, even before the adoption of the NAP, a good number of women in the Philippines had already been at the forefront of efforts to build peace. Many are engaged in peace education: raising awareness on the causes and effects of violence, discussing alternatives to get to a preferred future, and building capacities to broaden the peace constituency. Many are doing peace research through gathering data and collecting evidence that will inform both education and advocacy work. Many are 
into peace action: campaigning, lobbying, organizing, and networking to prevent and resolve armed conflicts and build a culture of peace.

There are also a number of women who take the lead or are actively involved in efforts such as disarmament and arms control, intercultural and interfaith understanding, challenging militarism, and upholding human rights. There are also women who actively take part in peace processes to find just and lasting solutions to the decades-old armed conflicts in the country which, combined, have claimed roughly 160,000 lives. Many serve or have served in various tracks of the peace processes-as members of peace panels, ceasefire monitors, consultants, and observers.

Prior to the current administration, the peace process between the Philippine government and the Moro Islamic Liberation Front was one occasion where women power was at its best. The chair of the government negotiating team was a woman. Both panels had women members. Advisers and technical working group members were largely women. Those in peace process mechanisms counted women in leadership. Women's networks such as the Women Engaged in Action on 1325 (WE Act 1325) were at the forefront of lobbying efforts to engender the peace agreement as well as the proposed law that would create greater autonomy for the Bangsamoro in Mindanao.

The Moros, or Bangsamoro people, are the Islamic populations who originally inhabited and ruled Mindanao before Spanish and American colonial rule. Islam arrived in Mindanao in the fourteenth century, two hundred years prior to colonization. The Moros were able to resist Spanish conquest until the United States took over in 1898. Spain ceded the Philippines, including Mindanao, to the United States for US\$ 20 million in December 1898 via the Treaty of Paris. The Moros have since then protested what they called "forced annexation." In the twentieth century, the government promoted the migration of people from Luzon and the Visayas. The Moros became minorities in their homeland and lost lands to the migrant settlers. Migration policies resulted in minoritization, displacement, landlessness, deprivation, and discrimination. In 1903, Moros comprised 76 percent of the Mindanao population. By 2000, they were the minority at 20.6 percent (Coronel-Ferrer 2014).

The Moro separatist movement, led by the Moro National Liberation Front (MNLF), was born in 1968. It wanted a separate homeland for the Muslims in Mindanao and, hence, waged a war against the Philippine government. However, a peace pact was signed in 1996 between the government and the MNLF which ended the war between the two parties. This peace agreement granted autonomy to geographical areas in Mindanao with a Muslim majority and created what is now known as the Autonomous Region of Muslim Mindanao (ARMM). However, some members of the MNLF broke ties with the group to continue the fight for liberation. The splinter group which named itself the Moro Islamic Liberation Front (MILF) severed its ties from the MNLF in 1984. But in 1997, the 
MILF started negotiating for peace with the government to address the legitimate grievances of the Bangsamoro.

The end of the armed conflict was in sight with the completion of the Framework Agreement on the Bangsamoro (FAB) in 2012, a preliminary peace agreement which called for the creation of an autonomous entity, the Bangsamoro Autonomous Region, which would replace the Autonomous Region of Muslim Mindanao. The FAB, thanks to women's active involvement in the peace process, included a provision on the right of women to meaningful participation in governance and decision-making processes. This provision was also enshrined in the Comprehensive Agreement on the Bangsamoro (CAB), the final peace agreement signed by both parties in 2014 .

The CAB provided for the creation of the Bangsamoro Basic Law (BBL) which, if passed by the Philippine Congress, would establish the new autonomous political entity known as the Bangsamoro Autonomous Region to replace the ARMM. Again, women worked to make sure that language in the proposed law would reflect their desire to meaningfully participate in political affairs and decision-making mechanisms. The lobbying efforts have not been futile. The draft bill contained several provisions asserting women's right to meaningful participation.

The passage of the bill and the creation of the Bangsamoro Government were imminent. Completion of the peace process was going to be a victory, especially for the women who actively worked in the four different tracks of the peace process: official peace negotiations (track 1); unofficial actors-church leaders, civil society leaders, member of the academia-dialoguing with official actors in the peace negotiations (track 1.5); unofficial actors working together to inform the official peace negotiations (track 2); and grassroots level initiatives to inform the official peace negotiations (track 3).

On January 25, 2015, however, a police operation in Mamasapano, Maguindanao meant to capture an alleged Malaysian terrorist resulted in an encounter between the Philippine National Police's Special Action Force (SAF) and the MILF. The SAF entered Mamasapano without coordinating with the military and the MILF. With both groups heavily armed, the encounter resulted in the death of forty-four members of the SAF and eighteen members of the MILF and the Bangsamoro Islamic Freedom Fighters (BIFF).

The Mamasapano clash, which resulted in the death of "Christian" police from an unfortunate encounter with the Moros, led to public indignation that fanned the fire of discrimination against the Moro people. Hate messages against Moros were all over broadcast and social media. Public opinion turned heavily against the peace process in general and the BBL in particular. Mamasapano unearthed deep-seated biases Christians have against the Moro population. Challenging these prejudices became a daunting yet necessary task to save the peace process and to pursue peace in Mindanao. 
Women peace advocates organized and joined several conversations to save the peace process. How can gains be preserved? How can the peace process constituency be saved and broadened in the aftermath of Mamasapano? How can the biases against the Moros and the peace process being blasted in media be challenged and countered?

Women peace advocates from government, the security sector, and civil society got together to discuss how they could help. If they organized a national peace education camp attended by Muslim, Christian, and indigenous youth leaders, would it help shape beliefs and attitudes that are more supportive of peace and the peace process? Would it help shape beliefs and attitudes more supportive of arms control, social justice, diversity, and women and youth agency?

\section{Objectives}

This study seeks to determine the effects of a women-led and organized peace education camp on youth leaders' attitudes towards peace and the peace process. Specifically, the study is an endeavor to answer the following questions: (1) are there significant differences in the scores of youth leaders prior to the peace education camp and after the training; and (2) are there significant differences in the beliefs and attitudes between Muslim and Christian youth leaders before and after the peace education camp?

\section{Review of Literature}

Peace education is education that promotes a culture of peace and is essentially transformative. Its purpose is to create social structures and patterns of thought that will reject violence and eliminate social injustice. Cora Weiss of the Hague Appeal for Peace posited that "to sustain a long-term change in the thought and action of future generations... our best contribution would be to work on peace education" (Castro and Galace 2010).

Is peace education indeed effective in transforming mindsets and attitudes? Women peace educators in the Philippines have conducted projects and studies to see if peace education or related efforts impact participants' attitudes and beliefs.

A study done by Galace (2003) investigated the effects of peace education on prejudice reduction. It sought to find out if gain scores of the group who went through peace education were significantly higher than the gain scores of those in a control group. The study used a quantitative methodology supplemented by qualitative data. One hundred and seventy-one high school students, ages ranging from twelve to fourteen participated in the research: eighty-seven were in the experimental group and eighty-four in the control group. A researcherdeveloped Likert scale was used to measure changes in attitudes. The data 
analysis procedures used the t-test for paired and independent samples. Results of the study showed that the gain scores of the students who went through peace education training were statistically higher $(\mathrm{p}<0.05)$ than the gain scores of the students in the control group, indicating that peace education significantly reduced students' attitudes of prejudice. Galace's research tested a theory posited by Gordon Allport (1954) who proposed that under certain conditions, contact between members of groups coming from diverse backgrounds can work to reduce prejudice and intergroup conflict.

A study conducted by Castro, Galace, and Lesaca (2005) sought to discover changes in students' attitudes after taking peace-focused courses. A qualitative self-evaluation was administered to 458 female and male students from three academic institutions, ages ranging from thirteen to seventeen. Among the respondents, 95.2 percent indicated positive change in attitudes on the issue of armed conflict and war after attending a peace-focused subject. Some of the changes reported were the realization that conflicts should be resolved in a peaceful way and that war was not a solution. Also, 98.4 percent of respondents indicated positive attitude change toward diversity after attending a peace-focused subject. Participants indicated that they learned to respect the beliefs, religions, and cultures of others and not to discriminate against those who differed from them. They reported realizing that all humans are equal and that everyone should be treated equally despite cultural and religious differences.

Pag-asa, a newsletter of the Twinning Project between Muslim and Christian Youth initiated by the Center for Peace Education (CPE) in 2004 and published annually, reflects changes in attitudes and beliefs of its Muslim and Christian participants. Their contributions, including essays, poems, and drawings, show how attitudes and beliefs about each other have changed in the process (Castro 2009). A young Muslim participant, for example, wrote, "We became close despite the differences. Whatever antagonism there was between us disappeared. It was replaced by understanding." The Twinning Project sought to build bridges of friendship between students of different faiths and cultures. For many years since the Twinning Project started, letters were exchanged between the Muslim and Christian students involved in the project.

A study conducted by Natividad, Galace, and Viar (2014) sought to find if Moro, indigenous, and Christian women's beliefs and attitudes toward arms control and other peace issues will change after a peace training. It also inquired into if such training will improve the community women's faith on their agency to provide peace and security in their conflict-affected communities. An internally validated twenty-two-item Likert-type scale was administered prior to and after the peace training to measure changes. One hundred and fifty-seven women from conflict-affected areas in the provinces of Lanao del Norte, Tawitawi, Zamboanga, and Cotabato in Mindanao participated in the study. Posttest scores using ANOVA indicated significant differences particularly on issues 
such as arms control $(\mathrm{F}(127)=2.966, \mathrm{p}+0.035)$ and participation in peace, human rights, security work, and governance $(\mathrm{F}(164)=2.855, \mathrm{p}+0.039)$. Specifically, the peace training helped change participants' views that guns were necessary in providing personal and community security. It also convinced women that they can be effective participants in building peace and promoting security in their communities.

This review indicates that women's initiatives to educate for peace have been successful in transforming mindsets and attitudes towards peace. Previous studies, though, did not show if there were significant differences on attitudinal changes between Muslims and Christians. They also did not focus on participants' attitudes towards the peace process especially at the height of media hype against the Muslim minority.

\section{Theoretical and Conceptual Framework}

In her work "Cycle of Socialization Theory," Harro (2000) posited that humans are born into a world where prejudices are already in place. These prejudices are reinforced in the family and institutions where humans are socialized. The cycle is perpetuated when we do nothing, giving birth to victims and perpetrators of violence of both the physical and psychological kind. However, this cycle may be interrupted through awareness-raising and education. Harro has been teaching for the last two decades and has been working in the field of social justice education raising awareness on challenges to peace such as racism and heterosexism. Figure 1 was devised by Harro and forms the basis of this study's theoretical framework.

This research will examine if beliefs and attitudes towards peace and the peace process can change after a peace education camp.

\section{Methodology}

This study is quantitative in nature. It examines the effects of a women-led and organized peace education camp on the beliefs and attitudes toward peace and the peace process of youth leaders in the aftermath of violence blamed by the Christian majority on the Muslim minority. Why peace education and why measure beliefs and attitudes? Because peace education "seeks to transform peoples' mindsets, attitudes and behaviors that, in the first place, have created or exacerbated violent conflicts" (Castro and Nario-Galace 2010). The peace camp included workshops, dialogues, and discussions on key peace education themes such as challenging prejudice and building tolerance, challenging war, resolving and transforming conflicts, upholding human dignity, women, peace and security, 
Figure 1. Theoretical Framework

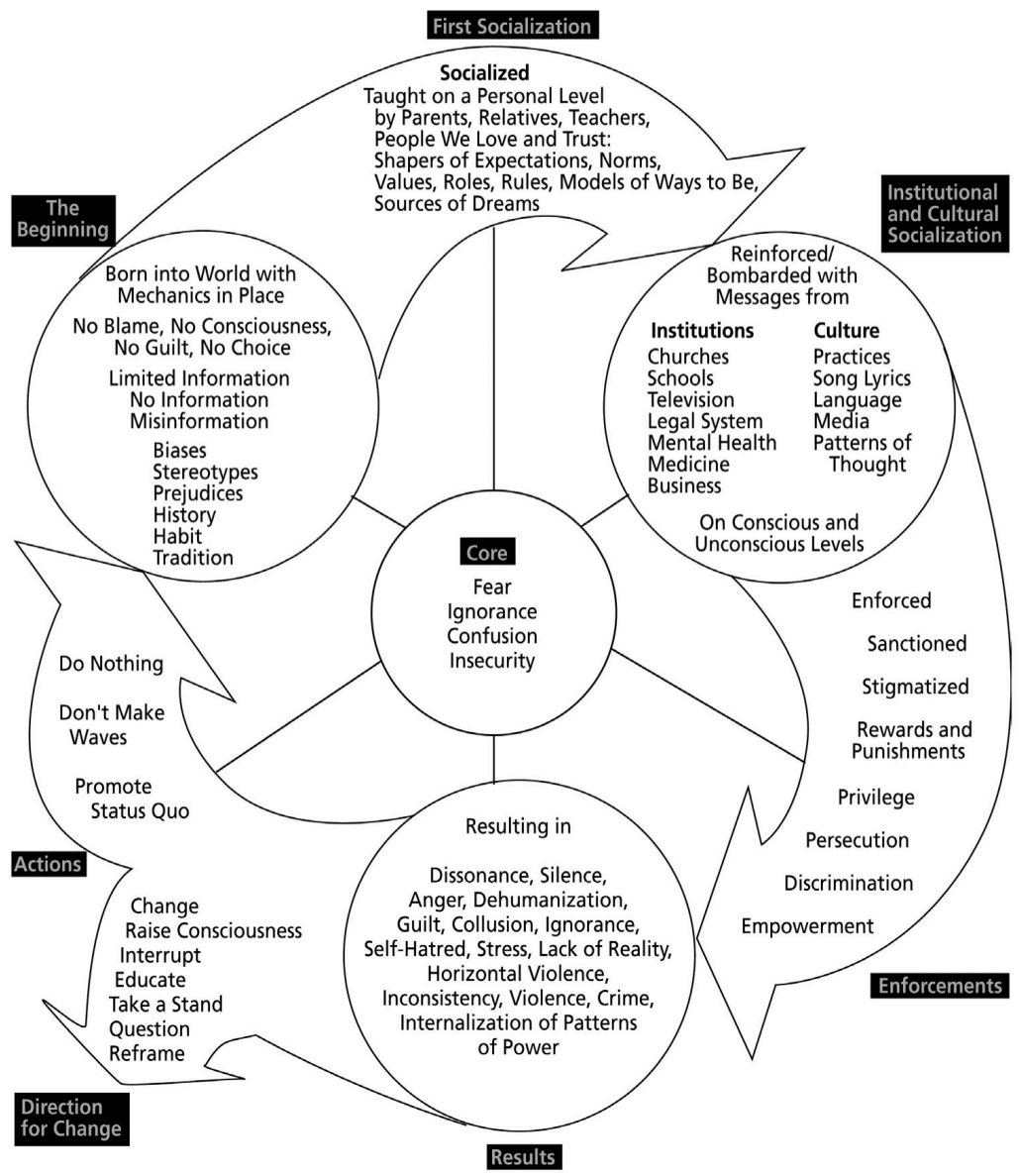

Source: Harro $(2000,16)$

Figure 2. Conceptual Framework

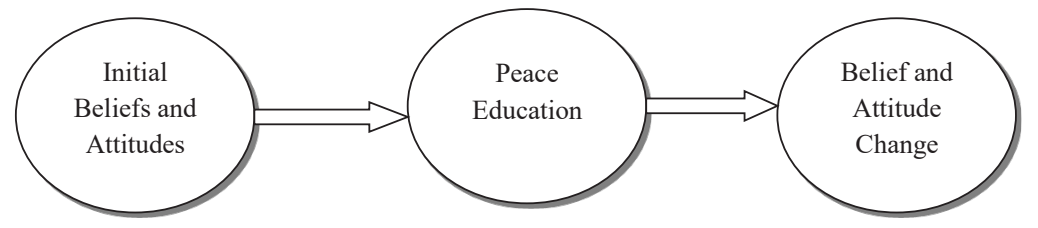

Source: Author

social justice and development, disarmament and normalization, peace processes, and youth as agents of peace.

Women peace advocates from government, the security sector, and civil 
society came together to discuss how they could help out. If they organized a national peace education camp attended by Muslim, Christian, and indigenous youth leaders, would it help shape beliefs and attitudes that are more supportive of peace and the peace process? Would it help shape beliefs and attitudes more supportive of arms control, social justice, diversity, and women and youth agency?

The study was conducted in a peace camp designed to provide contextual knowledge on the Mindanao conflict and the peace process. The peace camp was held for six days in April 2016, with the first three days spent on discussing general concepts of peace and conflict and the last three days spent in Cotabato in Mindanao, a site of armed conflict and the infamous Mamasapano incident. The last three days allowed the participants to speak with peace advocates on the ground as well as people directly affected by the armed conflict, including the Mamasapano incident.

Sampling is purposive and included all seventy participants of the peace camp. Participants were student leaders from colleges and universities throughout the Philippines. They differed in the following characteristics: sex, socioeconomic status, ethnicity, and religion.

The instrument used was the Beliefs and Attitudes toward Peace Issues (BATPI) scale developed by the researcher. It is a twenty-five-item Likert-type scale designed to measure beliefs and attitudes of the youth toward peace and the peace process.

Due to resource limitations, both human and material, the study did not aim to measure if beliefs and attitudinal changes would be complemented by behavioral changes after the peace education camp. Analysis would also be based largely on the results of the survey.

The following describes the measured dimensions which are drawn from the objectives of the peace camp and key peace education themes discussed in the camp: conflict resolution-acceptance of the problem-solving approach by way of dialogue or nonviolence vis-à-vis other response options such as aggression and passivity; social justice-acceptance that justice is an integral part of peace; acceptance of diversity-acceptance of the different other in general and the quest of the Bangsamoro people for greater autonomy in particular; women's participation-acceptance of women's participation in the public sphere of life particularly in political affairs in view of the fact that women are normally rendered invisible in the public space; transitional justice-acceptance that justice can be served if there was recognition and acknowledgement of injustice committed against a group of people in general and the Bangsamoro people in particular; youth agency-acceptance that the youth can be a potent force in peacebuilding; normalization-acceptance that peace and normalcy will be more likely if the number of arms are reduced, their proliferation controlled, and armed groups were disbanded; and belief in the Mindanao peace process- 
Table 1. Score Interpretation

\begin{tabular}{l|l}
\hline \hline \multicolumn{1}{c|}{ Score Range } & \multicolumn{1}{c}{ Interpretation } \\
\hline $1.00-1.49$ & Very Low Agreement \\
\hline $1.5-2.49$ & Low Agreement \\
\hline $2.5-3.49$ & High Agreement \\
\hline $3.5-4.00$ & Very High Agreement \\
\hline
\end{tabular}

Source: Author

acceptance that the peace negotiations and their by-products such as the $\mathrm{CAB}$ and the proposed BBL are pathways to peace in Mindanao.

The initial pool of items was generated based on the following documents and sources: (1) scales previously developed by Dr. Loreta Castro and Dr. Jasmin Nario-Galace which were used in their dissertations; (2) the experience of this researcher as an active civil society participant in the Mindanao peace process; and (3) personal experience as peace educator and activist.

Three experts-a peace educator, a member of the legal team of the GPH peace panel, and an educational psychologist-statistician-were consulted for content validation. Experts were requested to indicate whether the items were suitable, clear, and appropriate in relation to the scale's predetermined objectives per dimension. Twenty items were initially constructed. Five items and one dimension were added, and four items were reformulated upon the experts' suggestion.

The instrument has a five-point scale, using strongly agree, agree, undecided, disagree, and strongly disagree as options. Thirteen of the items are negatively oriented. These were factored into the analysis. Table 1 shows the interpretation of the scores. The scale was pilot-tested with thirty-three first year college students from Miriam College. Fifteen items were found to be most reliable in the item analysis with a Cronbach Alpha of .796.

The peace camp was designed by women peace advocates from the security sector, government peace panel, and academia, and had three major parts. In the first part, participants learned about general concepts of peace and conflict and key peace education themes, obstacles to peace and ways used to challenge these obstacles, the Mindanao and Moro struggle for peace and justice, the Mindanao peace process, and conflict resolution. The second part was held in Cotabato Province where participants were briefed on ceasefire mechanisms, faith traditions as resources for peace, media and peace, and peace advocacy. In between sessions, the participants traveled to Mamasapano, Maguindanao to meet and speak with community members affected by the infamous Mamasapano encounter.

The BATPI was administered to all participants prior to and after the peace 
camp. Only fifty-one of the seventy retrieved questionnaires were used for analysis. Nineteen questionnaires had to be disregarded because of the absence of either the pretest or the posttest.

The following statistical techniques were used: (1) descriptive statistics such as mean scores and standard deviation to show the profile of the participants in their pretest and posttest scores; (2) a t-test for independent samples was used to determine significant differences between the pretest and posttest scores of Muslim and Christian participants; and (3) a paired-samples t-test was used to determine significant differences in the scores of youth leaders before and after the peace education camp training.

\section{Results and Discussion}

Table 2 reveals that participants had low support for the propositions that war is an effective way of resolving conflicts, that physical violence has to be met with the same violence, that revenge is an acceptable response when harmed, and that conflicts are best settled through the use of force (Mean=1.78). This low agreement to said propositions further declined after the peace camp $($ Mean=1.24).

Before the peace camp, participants had low acceptance of the suggestions that equitable redistribution of wealth can contribute to peace and that the unevenness in the distribution of wealth in the country is a major cause of

Table 2. Beliefs and Attitudes of Youth Leaders in the Different Dimensions of Peace Before and After the Peace Education Training

\begin{tabular}{l|c|l|c|l}
\hline \multirow{2}{*}{\multicolumn{1}{c|}{ Variable }} & \multicolumn{2}{c|}{ Pretest } & \multicolumn{1}{c}{ Posttest } \\
\cline { 2 - 5 } & Mean & \multicolumn{1}{c}{ Interpretation } & Mean & \multicolumn{1}{c}{ Interpretation } \\
\hline Conflict Resolution & 1.78 & Low Agreement & 1.24 & Very Low Agreement \\
\hline Social Justice & 2.09 & Low Agreement & 2.74 & High Agreement \\
\hline Acceptance of Diversity & 2.38 & Low Agreement & 2.47 & Low Agreement \\
\hline Women's Participation & 1.69 & Low Agreement & 1.51 & Low Agreement \\
\hline Transitional Justice & 2.86 & High Agreement & 3.14 & High Agreement \\
\hline Youth Agency & 2.41 & Low Agreement & 2.22 & Low Agreement \\
\hline Normalization & 2.65 & High Agreement & 3.44 & High Agreement \\
\hline $\begin{array}{l}\text { Peace Process Between } \\
\text { Government and MILF }\end{array}$ & 3.16 & High Agreement & 3.72 & Very High Agreement \\
\hline Overall & 2.08 & Low Agreement & 2.54 & High Agreement \\
\hline
\end{tabular}

Source: Author 
peacelessness (Mean=2.09). After the peace camp, these propositions were highly accepted by the participants (Mean=2.74).

Further, acceptance of diversity and women's participation in political affairs are also highly accepted by the youth leaders and sustained in the posttest. Likewise, the high agreement (Mean=2.86) with the idea that there is a need to correct historical injustices against the Moro was also sustained in the post-test (Mean=3.14). The role of youth in the building of a culture is highly accepted by youth leaders (Mean=2.41) and was sustained in the post-test (Mean=2.22).

Participants highly accepted that peace and normalcy can be achieved if private armies were disbanded and firearms were reduced and controlled (Mean=2.65), and this was strengthened after the peace camp (Mean=3.44). Participants also highly supported the propositions that the peace process between the government and the MILF and the passage of the BBL can help bring about peace and that the peace agreement must continue despite the non-passage of the BBL prior to the peace camp (Mean=3.16). This support increased in the post-test $($ Mean=3.72).

Overall, results indicate that support for peace, peace-related issues, and the peace process before the camp $($ Mean=2.08) increased following the education provided at the camp $($ Mean=2.54).

As seen in Table 3, the high acceptance of the youth leaders of the importance of women participation in the peace process was sustained even

Table 3. Results of the Paired Samples T-Test

\begin{tabular}{|c|c|c|c|c|c|c|c|}
\hline & & \multicolumn{3}{|c|}{ PAIRED DIFFERENCES } & \multirow[b]{2}{*}{ T-Value } & \multirow[b]{2}{*}{$\mathrm{DF}$} & \multirow[b]{2}{*}{ P-Value } \\
\hline & & Mean & $\begin{array}{l}\text { Standard } \\
\text { Deviation }\end{array}$ & $\begin{array}{c}\text { Standard } \\
\text { Error Mean }\end{array}$ & & & \\
\hline Pair 1 & Conflict - Preconflict & -.5404040 & .6343472 & .1104257 & -4.894 & 32 & $.000^{\star *}$ \\
\hline Pair 2 & Social - Presocial & .6505376 & .8749125 & .1571389 & 4.140 & 30 & $.000^{* *}$ \\
\hline Pair 3 & Diversity - Prediversity & .0911458 & .6944349 & .1227599 & .742 & 31 & .463 \\
\hline Pair 4 & Women - Prewomen & -.1770833 & .9578365 & .1693232 & -1.046 & 31 & .304 \\
\hline Pair 5 & $\begin{array}{l}\text { Transitional - } \\
\text { Pretransitional }\end{array}$ & .2833333 & .6449776 & .1177563 & 2.406 & 29 & $.023^{\star}$ \\
\hline Pair 6 & $\begin{array}{l}\text { Normalization - } \\
\text { Prenormalizatoin }\end{array}$ & .7917 & .8330 & .1700 & 4.656 & 23 & $.000^{\star *}$ \\
\hline Pair 7 & Youth - Preyouth & -.1969697 & .4496421 & .0782726 & -2.516 & 32 & $.017^{\star}$ \\
\hline Pair 8 & Peace - Prepeace & .5611111 & .7264612 & .1326331 & 4.231 & 29 & $.000^{\star *}$ \\
\hline Pair 9 & Overall - Preoverall & .4663400 & .3145681 & .0547593 & 8.516 & 32 & $.000^{\star *}$ \\
\hline
\end{tabular}

${ }^{\star} \mathrm{p}<.05 ;{ }^{* *} \mathrm{p}<.01$

Source: Author 
after the peace camp. Thus, no significant difference was reflected $(\mathrm{t}(31)=$ $-1.046, \mathrm{p}=.304)$. Acceptance of diversity was also sustained after the peace camp $(\mathrm{t}(30)=4.140, \mathrm{p}=0.463)$.

On the other hand, findings revealed that after the peace camp, the youth leaders have beliefs and attitudes that became more supportive of peaceful conflict resolution approaches $(\mathrm{t}(32)=-4.894, \mathrm{p}=.000)$, the peace process $(\mathrm{t}(29)=4.231$, $\mathrm{p}=.000)$, social justice $(\mathrm{t}(30)=4.140, \mathrm{p}=.000)$, and transitional justice $(\mathrm{t}(29)=2.406$, $\mathrm{p}=.023)$. In addition, significant differences were found in the acceptance of youth as a potent force in peacebuilding $(\mathrm{t}(32)=-2.516, \mathrm{p}=.017)$ and acceptance that peace and normalcy will be more possible if arms are reduced, their proliferation controlled, and armed are groups disbanded $(\mathrm{t}(23)=4.656, \mathrm{p}=.000)$.

On the whole, the change after the peace camp was highly significant $(\mathrm{t}(32)=8.516, \mathrm{p}=.000)$ indicating that peace education, in this case via a peace camp, was successful in its goal of sustaining and shaping mindsets and attitudes supportive of peace and the peace process.

Generally, Christian and Muslim youth in the Philippines are socialized apart and differently. There have been reports of prejudice and exclusion, particularly against the Muslim minority (Castro 2009). Women in many Islamic homes have been socialized into thinking that they are inferior to men and should focus on reproductive roles, limiting what they are able to achieve and their contributions to peace (Natividad, Galace, and Viar 2014). It is interesting, then, to see if two groups of people differing in ethnicity, religion, culture, and geographical location have differing beliefs on matters that relate to peace and security, women, and youth agency.

Table 4 shows the items that have significant differences between Christians and Muslims. In the pretest, only two items of the twenty-five items show significant differences, while after the intervention five items were found to have significant differences among Christians and Muslims.

Before the intervention, both Muslim and Christian youth already supported women's political participation. Both pretest and posttest scores, however, indicated that belief in women's agency is significantly higher for Christian than Muslim youth. It is interesting to note that after the intervention, Christian youth scored significantly higher than the Muslim youth in statements supporting transitional justice and acceptance of diversity, although both groups highly supported these statements in both pretest and posttest.

Posttest scores also demonstrated that both Muslim and Christian youth agreed very highly that the youth is an effective force in building a culture of peace. Posttest scores showed, however, that Muslim youth's support for the proposition that youth is an effective force in building a culture of peace is significantly higher compared to their Christian counterpart.

Overall, however, there is no significant difference between Christians and Muslims in relation to their beliefs and attitudes before $(t(51)=-1.745, p=0.087)$ 
Table 4. Beliefs and Attitudes of Muslim and Christian Youth Leaders Before and After the Peace Education Camp: Results of the T-test for Independent Samples

\begin{tabular}{|c|c|c|c|c|c|c|c|}
\hline \multirow{2}{*}{$\begin{array}{l}\text { Type of Test } \\
\text { (Item No.) }\end{array}$} & \multicolumn{2}{|c|}{ Christian $(\mathrm{N}=34)$} & \multicolumn{2}{|c|}{ Muslim (N=17) } & \multirow{2}{*}{$\begin{array}{c}\text { Mean } \\
\text { Difference }\end{array}$} & \multirow{2}{*}{ T-Value } & \multirow{2}{*}{ P-Value } \\
\hline & Mean & Interpretation & Mean & Interpretation & & & \\
\hline $\begin{array}{l}\text { Pretest ( } 8) \text { - The } \\
\text { place of the women } \\
\text { is in the home. }\end{array}$ & 1.51 & $\begin{array}{l}\text { Low } \\
\text { Agreement }\end{array}$ & 2.00 & $\begin{array}{l}\text { Low } \\
\text { Agreement }\end{array}$ & -0.486 & -2.077 & $0.043^{\star}$ \\
\hline $\begin{array}{l}\text { Pretest (12) - Men } \\
\text { should have greater } \\
\text { share in political } \\
\text { power than women. }\end{array}$ & 1.24 & $\begin{array}{l}\text { Very Low } \\
\text { Agreement }\end{array}$ & 1.75 & $\begin{array}{l}\text { Low } \\
\text { Agreement }\end{array}$ & -0.508 & -2.389 & $0.026^{*}$ \\
\hline $\begin{array}{l}\text { Posttest (11) - } \\
\text { Recognition and } \\
\text { acknowledgment of } \\
\text { a wrong done to a } \\
\text { group of people is not } \\
\text { necessary for healing } \\
\text { and reconciliation. }\end{array}$ & 1.50 & $\begin{array}{l}\text { Low } \\
\text { Agreement }\end{array}$ & 2.16 & $\begin{array}{l}\text { Low } \\
\text { Agreement }\end{array}$ & -0.0658 & -2.145 & 0.042 \\
\hline $\begin{array}{l}\text { Posttest (12) - Men } \\
\text { should have greater } \\
\text { share in political } \\
\text { power than women. }\end{array}$ & 1.17 & $\begin{array}{l}\text { Very Low } \\
\text { Agreement }\end{array}$ & 1.89 & $\begin{array}{l}\text { Low } \\
\text { Agreement }\end{array}$ & -0.728 & -4.033 & $0.001^{\star *}$ \\
\hline $\begin{array}{l}\text { Posttest (15) - It } \\
\text { will not be good for } \\
\text { the country if the } \\
\text { Bangsamoro people } \\
\text { will be given the } \\
\text { right to participate } \\
\text { in the exploration, } \\
\text { development, and } \\
\text { utilization of natural } \\
\text { resources within } \\
\text { their proposed } \\
\text { Bangsamoro } \\
\text { territory }\end{array}$ & 1.66 & $\begin{array}{l}\text { Low } \\
\text { Agreement }\end{array}$ & 1.26 & $\begin{array}{l}\text { Very Low } \\
\text { Agreement }\end{array}$ & 0.394 & 2.011 & $0.050^{*}$ \\
\hline $\begin{array}{l}\text { Posttest (17) - The } \\
\text { youth is an effective } \\
\text { force in building a } \\
\text { culture of peace. }\end{array}$ & 3.54 & $\begin{array}{l}\text { Very High } \\
\text { Agreement }\end{array}$ & 3.95 & $\begin{array}{l}\text { Very High } \\
\text { Agreement }\end{array}$ & -0.407 & -2.267 & 0.029 \\
\hline $\begin{array}{l}\text { Posttest }(21) \text { - } \\
\text { Decisions on peace } \\
\text { and security must be } \\
\text { left with men. }\end{array}$ & 1.23 & $\begin{array}{l}\text { Very Low } \\
\text { Agreement }\end{array}$ & 1.67 & $\begin{array}{l}\text { Low } \\
\text { Agreement }\end{array}$ & -0.438 & -2.782 & $0.010^{*}$ \\
\hline
\end{tabular}

${ }^{\star} \mathrm{p}<.05 ;{ }^{* *} \mathrm{p}<.01$

Source: Author 
and after $(\mathrm{t}(51)=-1.403, \mathrm{p}=0.166)$ the peace education camp.

\section{Conclusion and Recommendations}

The results of this research validate previous studies that peace education positively contributes to shaping beliefs and attitudes supportive of peace and its related themes, namely, nonviolent conflict resolution, tolerance, social justice, and challenging war, militarism and proliferation of weapons (Galace 2003; Castro, Galace, and Lesaca 2004; Natividad, Galace, Viar 2014). The research, in addition, also demonstrates that peace education can help in shaping beliefs and attitudes supportive of the peace process even in crisis situations where the gains of the peace process are threatened.

Moreover, the study demonstrates that education may result in significant improvement on the youth's belief in and attitude towards their agency to build peace. It also establishes the usefulness of peace education in improving beliefs that arms should be controlled to build peace. However, it is interesting to note that although Christian and Muslim participants both believed in the importance of women's agency in promoting peace and security, the agreement of Christians to the proposition is significantly higher than the Muslim participants. This may be due to the cultural conditioning resulting from gender socialization that the women's place is in the home and not in public space.

Results of this study also validated the proposition of Allport (1954) that, under certain conditions, contact between members of groups coming from diverse backgrounds can work to reduce prejudice. The peace education camp gave space to participants to dialogue with those directly affected by armed conflict. This could be seen during the interactions between these groups during the closing ceremony and onwards; the participants later created a Facebook page on which they continue to share information and communicate in a collegial fashion.

Results also demonstrated that there is no significant difference, overall, between the Christian and Muslim youth in relation to their beliefs and attitudes towards peace and the peace process before and after the training program, indicating that peace and the peace process are appreciated regardless of religion and ethnicity.

Given these results, the following suggestions may be considered to further the goal of shaping beliefs, attitudes, and behaviors toward peace through education. First, incorporate opportunities for direct contact with victims of war and injustice in peace education training to effectively reduce biases between groups of diverse backgrounds. Second, create spaces in peace education training that allow for brainstorming on specific and doable strategies the youth can undertake to support the peace process and contribute to the overall goal of 
peacebuilding. Three, incorporate more strongly in the session on women, peace, and security the correlation between gender relations and violence from the home to the larger society for better appreciation of the importance of women's participation in peace and security processes and mechanisms. Fourth, continue organizing peace camps that are culturally and ethnically diverse as this also becomes an opportunity to foster intercultural understanding. Fifth, lobby for policies that will mandate educational institutions to integrate peace education into the curriculum to help broaden the peace constituency beginning with the youth.

\section{Implications for Future Strategies of Peacebuilding}

"To reach peace, teach peace."

Peacebuilding relates to practices aimed at transforming a society from a state of violence to a state of peace and includes practices in conflict prevention, conflict resolution, and post-conflict reconstruction. Educating the youth toward becoming agents of peace is central to the task of conflict prevention in particular and peacebuilding in general. Peace education seeks to transform the knowledge, skills, attitudes, and behaviors that have created violent conflict into knowledge, skills, attitudes, and behaviors supportive of peace and peacebuilding.

Peace education, however, as a pathway to building a culture of peace is underutilized and its usefulness hardly measured. This study aimed to show that peace education can be useful in shaping mindsets supportive of peace. Educating for peace need not be solely confined within the portals of the classroom and may have added benefits if the process is experiential and dialogical. This peace education camp allowed contact among youth of differing sexes, cultures, ethnicities, religions, and socio-economic statuses. The improvement in their beliefs and attitudes toward peace, the peace process, and youth and women's agency in getting to peace was most likely not only shaped by the "curriculum" content but also by the cross-cultural dialogue and interaction. The peace camp also allowed participants to visit the site of the Mamasapano clash where they had a chance to interview families who lost loved ones in the encounter. Visits to conflict-affected areas and interaction with families affected by war have most possibly contributed, as well, to positively shaping beliefs and attitudes supportive of peace and peacebuilding.

Hence, as the intervention helped shape beliefs and attitudes of the youth towards peace and the peace process even in the aftermath of a crisis situation, efforts of women peace advocates to educate the youth for peace should persist. Peace education will prepare new generations of socially active participants desperately needed in our world today. 


\section{Acknowledgements}

The author expresses gratitude to Cynthia Alcantara, Ph.D., for providing statistical analysis and to Loreta N. Castro, Ph.D., for her valuable comments. She also thanks General Lina Sarmiento and Atty. Amirah Pendatun whom she worked with in conceptualizing, designing, and implementing the peace education camp.

\section{References}

Allport, Gordon W. 1954. The Nature of Prejudice. London: Addison-Wesley.

Castro, Loreta. 2009. Building Bridges of Understanding and Peace: A Twinning Project between Muslim and Christian Youth. Quezon City: Center for Peace Education.

Castro, Loreta, and Jasmin Nario-Galace. 2010. Peace Education: A Pathway to a Culture of Peace. Quezon City: Center for Peace Education.

Castro, Loreta, Jasmin Nario-Galace, and K. Lesaca. 2005. Peace Education Initiatives in Metro Manila. Quezon City: UP CIDS.

Coronel-Ferrer, M. 2014. "Trust, Faith and the Comprehensive Agreement on the Bangsamoro" [PowerPoint Presentation]. Presented at Miriam College, Quezon City.

Coronel-Ferrer, M. 2005. Lessons Learned in Civil Society Peacebuilding. Quezon City: UP CIDS.

Galace, J. N. 2003. "The Effects of a Peace Education Program in Reducing Prejudice." Ph.D. dissertation, University of the Philippines, Quezon City.

Harro, Bobbie. 2000. “The Cycle of Socialization." In Readings for Diversity and Social Jusitice, eds. Maurianne Adams, Warren J. Blumenfeld, Carmelita (Rosie) Castaneda, Heather W. Hackman, Madeline L. Peters, Ximena Zuniga, 16-21. New York: Routledge.

Natividad, Ana, Jasmin Nario-Galace, and Iverly Viar. 2014. Women Speak: Perspectives on Normalization. Quezon City: WE Act 1325.

\footnotetext{
Jasmin Nario-Galace is Executive Director at the Center for Peace Education and Professor at the Department of International Studies, Miriam College, Quezon City, Philippines. She completed her MA in Peace Studies at the University of Notre Dame in Indiana, U.S.A. and her Ph.D. in Educational Psychology at the University of the Philippines, Diliman. She has published on peace education, conflict resolution, mediation, women, peace and security, and gender and disarmament. She has leadership roles in various organizations such as the Catholic Educational Association of the Philippines, Philippine Council for Peace and Global Education, Global Network of Women Peacebuilders, the International Action Network on Small Arms and Pax Christi-Asia Pacific. Email: jgalace@mc.edu.ph
} 